\begin{tabular}{|c|c|c|c|c|c|c|c|c|c|}
\hline & & & \multicolumn{4}{|c|}{$\begin{array}{l}\text { Study RA-BEAM } \\
\text { (0-240-52, data up to rescue) }\end{array}$} & \multicolumn{3}{|c|}{$\begin{array}{l}\text { Study RA-BUILD } \\
\text { (0-24, data up to rescue) }\end{array}$} \\
\hline & & & $\begin{array}{c}\text { PBO } \\
(N=488)\end{array}$ & $\begin{array}{l}\text { BARl } 4 \mathrm{mg} \\
(\mathrm{N}=487)\end{array}$ & \multicolumn{2}{|c|}{$\begin{array}{c}\text { ADA } \\
(\mathrm{H}=330)\end{array}$} & $\begin{array}{c}\begin{array}{c}P 80 \\
(N=228)\end{array} \\
\text { B }\end{array}$ & \multicolumn{2}{|c|}{$\begin{array}{l}\text { BARI } 2 \mathrm{mg} \text { BARI } 4 \mathrm{mg} \\
(N=229) \quad(H=227)\end{array}$} \\
\hline \multicolumn{3}{|c|}{ Total number of dose interruptons, I } & 67 & 62/103 & \multicolumn{2}{|c|}{$\begin{array}{l}30 \\
146\end{array}$} & 32 & 24 & 40 \\
\hline \multirow{2}{*}{\multicolumn{3}{|c|}{ Patients with $\geq 1$ interruption, $n$ (\% of W) }} & 54 (11.1) & $50(10.3) 75$ (15.4) & \multicolumn{2}{|c|}{$28(8.5) / 40(12.1)$} & $29(12.7)$ & $21(9.2)$ & $34(15.0)$ \\
\hline \multirow{2}{*}{\multicolumn{3}{|c|}{$\begin{array}{l}\text { Number of interrupsions per interrupted patient, mean } \\
\text { Time from first dose to first interruption, mean, days }\end{array}$}} & an 1.2 & \multirow{2}{*}{$\begin{array}{c}1.211 .4 \\
70.6 / 128.9\end{array}$} & \multicolumn{2}{|c|}{ 1.11/1.2 } & 1.1 & \multirow{2}{*}{$\begin{array}{r}1.1 \\
41.0\end{array}$} & 1.2 \\
\hline & & & \begin{tabular}{l|l}
5 & 68.9 \\
\end{tabular} & & & \begin{tabular}{l|l}
112.3 &
\end{tabular} & 53.1 & & 53.6 \\
\hline Duration of individ. & alinteruptions. & mean (SD), days & $\mathrm{s} \quad 11.7(13.2)$ & $11.4(9.4) / 15.1$ (15. & .7) $19.4(24.6)$ & 1/23.1(29.1) 11 & $11.6(10.2)$ & $12.3(12.6)$ & $10.7(9.8)$ \\
\hline \multicolumn{10}{|c|}{ Interruption duration categories, m (\% ofl) } \\
\hline \multicolumn{3}{|c|}{0.7 days } & $35(52.2)$ & $26(41.9) / 44(42.7)$ & \multicolumn{2}{|c|}{$10(33.3) / 15(32.6)$} & $16(50.0)$ & & $20(50.0)$ \\
\hline \multicolumn{3}{|l|}{$\begin{array}{l}\text { 8-14 days } \\
15-21 \text { days }\end{array}$} & $14(20.9)$ & \multirow{2}{*}{$\begin{array}{l}15(24.2) / 26(25.2) \\
5(8.1) 6(5.8)\end{array}$} & \multicolumn{2}{|c|}{$10(33.3) / 16(34.8)$} & $7(21.9)$ & \multirow{2}{*}{$\begin{array}{l}8(33.3) \\
4(16.7)\end{array}$} & $10(25.0)$ \\
\hline \multirow{2}{*}{\multicolumn{3}{|c|}{ 22-28 days }} & $6(9.0)$ & & \multirow{2}{*}{\multicolumn{2}{|c|}{$\begin{array}{l}4(13.3) / 4(8.7) \\
0 / 1(2.2)\end{array}$}} & $5(15.6)$ & & $4(10.0)$ \\
\hline & & & $3(4.5)$ & $5(8.1) / 14(13.6)$ & & & $1(3.1)$ & $0(0.0)$ & $3(7.5)$ \\
\hline \multicolumn{3}{|c|}{$>28$ days } & $5(7.5)$ & \multirow[t]{2}{*}{$4(6.5) / 13(12.6)$} & $5(16.7)$ & 110(21.7) & $3(9.4)$ & $2(8.3)$ & $3(7.5)$ \\
\hline Reason for intemur & ions, $n(\%$ of $N)$ & & & & & & & & \\
\hline Adverse even & & & $44(9.0)$ & $46(9.4) 68(14.0)$ & $26(7.9)$ & 137(11.2) & $24(10.5)$ & $16(7.0)$ & $26(11.5)$ \\
\hline Abnormal lab & :sult & & $10(2.0)$ & $3(0.6) 6(1.2)$ & & 20 & $4(1.8)$ & $5(2.2)$ & $6(2.6)$ \\
\hline Investigator d & ision & & $3(0.6)$ & $2(0.4) / 2(0.4)$ & $2(0.6)$ & $1 / 3(0.9)$ & $2(0.9)$ & 0 & $2(0.9)$ \\
\hline $\begin{array}{l}\text { abbreviations: ADA } \\
\text { nenumber of patitsts } \\
\text { "interruptions are ba } \\
\text { resumption of study }\end{array}$ & 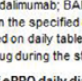 & 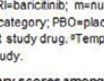 & $\begin{array}{l}\text { lumber of interruy } \\
\text { scebo. } \\
\text { peorary interrupt }\end{array}$ & uptions in the specift & fifed categony, $N$ & $\begin{array}{l}\text { Nenumber of } \\
\text { in holding of stu }\end{array}$ & atients in so & at is followed & \\
\hline Table 2. Summary & fePRO daily di & $\begin{array}{l}\text { ary scores among } \\
\text { Place }\end{array}$ & gatients retre & eated following stu & udyd & nuption: & Baricitinitiog & & \\
\hline & & $25(2$ & & & & & $54(52)^{\circ}$ & & \\
\hline Mean (SO) & $\begin{array}{l}\text { Study drug } \\
\text { initiation" }\end{array}$ & $\begin{array}{c}\text { Pre- } \\
\text { interruption' }\end{array}$ & $\begin{array}{l}\text { Last during } \\
\text { interruptione }\end{array}$ & $\begin{array}{c}\begin{array}{c}\text { Post- } \\
\text { interruption }\end{array} \\
\end{array}$ & $\begin{array}{l}\text { Studydrug } \\
\text { initiation }\end{array}$ & $\begin{array}{l}\text { Pre- } \\
\text { intervuption }\end{array}$ & $\begin{array}{ll}\text { Lasto } \\
\text { on' } \\
\text { intern }\end{array}$ & $\begin{array}{l}\text { during } \\
\text { ruption in }\end{array}$ & $\begin{array}{l}\text { Post- } \\
\text { interuptions }\end{array}$ \\
\hline MJS Duration & $\begin{array}{l}106 \\
(87)\end{array}$ & $\begin{array}{l}118 \\
(157)\end{array}$ & $\begin{array}{c}126 \\
(159)\end{array}$ & $\begin{array}{l}116 \\
(159)\end{array}$ & $\begin{array}{l}160 \\
(187)\end{array}$ & $\begin{array}{c}137 \\
(164)\end{array}$ & & 1.135 & $\begin{array}{l}121 \\
(188)\end{array}$ \\
\hline MJs Severity & $\begin{array}{l}5.5 \\
(2.1)\end{array}$ & $\begin{array}{l}4.3 \\
(2.0)\end{array}$ & $\begin{array}{c}4.5 \\
(2.0)\end{array}$ & $\begin{array}{c}4.2 \\
(1.9)\end{array}$ & $\begin{array}{c}5.8 \\
(2.0)\end{array}$ & $\begin{array}{l}4.2 \\
(2.2)\end{array}$ & & $\begin{array}{l}4.4 \\
2.22\end{array}$ & $\begin{array}{l}3.8 \\
(2.1)\end{array}$ \\
\hline Worst Joint Pain & $\begin{array}{l}5.8 \\
(1.7)\end{array}$ & $\begin{array}{l}4.6 \\
(2.0)\end{array}$ & $\begin{array}{l}4.9 \\
(2.0)\end{array}$ & $\begin{array}{l}4.4 \\
(1.9)\end{array}$ & $\begin{array}{l}6.1 \\
(2.0)\end{array}$ & $\begin{array}{l}4.6 \\
(2.2)\end{array}$ & & 2.7) & $\begin{array}{l}4.2 \\
(2.1)\end{array}$ \\
\hline Worst Tiredness & $\begin{array}{c}5.5 \\
(2.5)\end{array}$ & $\begin{array}{l}4.7 \\
(2.2)\end{array}$ & $\begin{array}{l}4.7 \\
(2.2)\end{array}$ & $\begin{array}{l}4.1 \\
(2.0)\end{array}$ & $\begin{array}{c}5.5 \\
(2.0)\end{array}$ & $\begin{array}{l}4.7 \\
(2.3)\end{array}$ & & $\begin{array}{l}4.9 \\
2.5)\end{array}$ & $\begin{array}{l}4.2 \\
(2.4)\end{array}$ \\
\hline
\end{tabular}

Asahi-kasei, YL Biologics, Sanofi, janssen, Eli Lilly and Company, GlaxoSmithKline, T. Cardillo Employee of: Eli Lilly and Company, D. Schlichting Employee of: Eli Lilly and Company, S. Beattie Employee of: Eli Lilly and Company, L. Chen Employee of: Eli Lilly and Company, T. Rooney Employee of: Eli Lilly and Company, J. Smolen: None declared

DOI: 10.1136/annrheumdis-2017-eular.1326

\section{FRI0125 RHEUMATOID ARTHRITIS PATIENTS WITH ANTI-ACETYLATED PEPTIDE ANTIBODIES STARTING THEIR FIRST TUMOR-NECROSE-FACTOR-INHIBITOR TREATMENT SHOW GREATER RESPONSE}

P. Studenic $^{1}$, S. Blüml ${ }^{1}$, H. Bang ${ }^{2}$, D. Sieghart ${ }^{1}$, D. Aletaha ${ }^{1}$, H. Haslacher ${ }^{3}$, T. Perkmann ${ }^{3}$, J.S. Smolen ${ }^{1,4}$, G. Steiner ${ }^{1} .{ }^{1}$ Internal Medicine 3, Division of Rheumatology, Medical University Vienna, Vienna, Austria; ${ }^{2}$ Orgentec Diagnostika, Mainz, Germany; ${ }^{3}$ Department of Laboratory Medicine, Medical University Vienna; ${ }^{4}$ Internal Medicine 2, Hietzing Hospital, Vienna, Austria

Background: Anti-acetylated-peptide antibodies (AAPA) have recently been described in rheumatoid arthritis (RA) patients.[1] Patients that show multiple autoantibody positivity have a higher likelihood to flare when stopping biological treatment. The role of AAPA antibodies for response to Tumor-Necrose-Factorinhibitor treatment (TNFi) has not been explored.

Objectives: To determine the prevalence and serological overlap of AAPA to rheumatoid factor (RF) and anti-citrullinated protein antibodies (ACPA) in a cohort of RA patients starting their TNF-inhibitor, and to assess their relation of autoantibody status to response to therapy.

Methods: We measured AAPA by ELISA using two acetylated peptides derived from vimentin, as well as RF and ACPA. We evaluated the prevalence of autoantibodies, baseline characteristics of autoantibody positive and negative patients, and their association with a $50 \%$ response by the Simplified disease activity index (SDAI50), and with achieving of SDAl low disease activity or remission at 6 months after starting the first TNFi. Likelihood ratios were calculated from logistic regression analyses. To better determine differences in SDAl change over time General Estimated Equation analyses (GEE) was used. Results: Among our 93 patients starting treatment on a TNFi ( $85 \%$ female, mean disease duration: $7.7 \pm 7$ years mean SDAI $20 \pm 13$ ), $50 \%$ were positive for AAPA, $57 \%$ for ACPA and $61 \%$ for RF (for overlap of antibodies see figure). There were no significant differences in baseline characteristics found between AAPA positive and negative patients. $61 \%$ of patients reached LDA or REM and $33 \%$ achieved an SDAl50 response after 6 months of TNFi treatment. AAPA positive patients showed a likelihood ratio $(\mathrm{LR}+)$ of $5.3(\mathrm{p}=0.022)$ to achieve an SDAI50 response and $3.9(p=0.048)$ to reach LDA/REM. In contrast, being RF or ACPA positive did not coincide with a higher likelihood of achieving SDAI50 ( $L R+$ of 0.08 ; $p=0.773$ and $1.09 ; p=0.297$, respectively) or LDA/REM ( $L R+$ of $1.83 ; p=0.177$ and $1.55 ; p=0.213$ ). Relative changes upon treatment with TNFi in composite scores were neither different between RF+ vs. RF- patients, nor between ACPA+ vs ACPA-patients; however AAPA+ showed significantly higher relative changes in SDAI $(p=0.021), \operatorname{CDAI}(p=0.025)$ and DAS $(p=0.022)$ compared to AAPA- patients. Of note, relative changes in CRP were similar between the groups.

GEE on up to 230 days of TNFi treatment or until change of treatment, showed no significant difference in SDAl courses comparing RF+ vs RF- or ACPA+ vs ACPA-

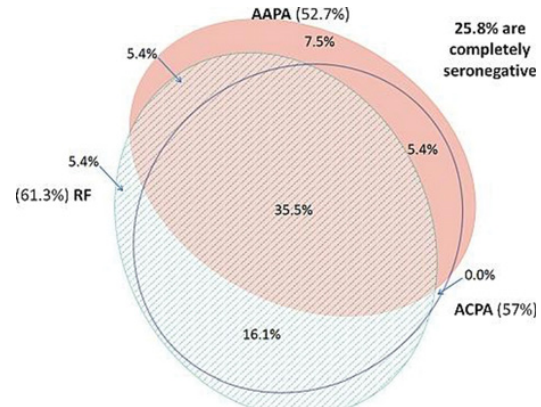

Figure 1. Overlap of RF, ACPA and AAPA positive patients.

patients; but for AAPA+ vs. AAPA- patients the difference in change in SDAI was significant $(p=0.045)$ over time.

Conclusions: AAPA positivity, in contrast to RF and ACPA positivity, appears to have a tighter association with greater levels of response in patients who are initiating TNFi-treatment. Therefore, AAPA might add additional information to estimate the chances of RA patients for responding to TNF-inhibitors.

References:

[1] Juarez M, Bang H, Hammar F, et al. Identification of novel antiacetylated vimentin antibodies in patients with early inflammatory arthritis. Ann Rheum Dis 2016;75(6):1099-107.

Disclosure of Interest: None declared

DOI: 10.1136/annrheumdis-2017-eular.5374

\section{FRI0126 AIMING FOR REMISSION ACCORDING TO ANY OF THE RHEUMATOID ARTHRITIS DISEASE ACTIVITY INDICES IS MORE IMPORTANT FOR PHYSICAL FUNCTION THAN THE ACTUAL CHOICE OF INDEX: A LONGITUDINAL ANALYSIS IN A CLINICAL PRACTICE SETTING (METEOR COHORT)}

${ }_{\text {P.D. Carvalho }}{ }^{1}$, R. Ferreira ${ }^{1}$, R. Landewé ${ }^{2}$, D. Vega-Morales ${ }^{3}$

K. Salomon-Escoto ${ }^{4}$, D.J. Veale ${ }^{5}$, J. da Silva ${ }^{1}$, P.M. Machado ${ }^{6} .{ }^{1} \mathrm{CHUC}$, Coimbra, Portugal; ${ }^{2}$ ARC, Amsterdam, Netherlands; ${ }^{3}$ HU/UANL, Monterrey, Mexico; ${ }^{4}$ UMass, Massachusetts, United States; ${ }^{5}$ DAMC, Dublin, Ireland; ${ }^{6}$ UCL, London, United Kingdom

Background: The association between remission and disability in patients with rheumatoid arthritis (RA) has been established mainly in clinical trial cohorts and not in "real-life" patients. Moreover, only a limited number of remission definitions have been tested.

Objectives: To compare the association between different remission criteria and physical function in patients with RA followed in clinical practice.

Methods: Longitudinal data from the METEOR database were used. Fifteen definitions of remission were tested: ACR-EULAR boolean-based; Simplified Disease Activity Index (SDAI); Clinical Disease Activity Index (CDAI); Disease Activity Score (DAS) and 28-joint count DAS (DAS28), both with ESR/CRP, with $3 / 4$ variables $(3 \mathrm{v} / 4 \mathrm{v})$, and various cut-offs tested. Disability was measured by the Health Assessment Questionnaire $(\mathrm{HAQ})$ and $\mathrm{HAQ} \leq 0.5$ was defined as a good outcome. Associations were investigated using generalised estimating equations (GEE), using $\mathrm{HAQ}<0.5$ as dependent variable and the various remission criteria as independent variables. Potential confounding factors (age, body mass index, gender, rheumatoid factor positivity, erosions and biologic treatment) were also tested. Sensitivity analyses were performed using first visits only and using patients with no missing data for all definitions of remission.

Results: Data from 32,915 patients and 157,899 visits were available. The most stringent definition of remission (table 1) was the ACR-EULAR boolean definition $(4.5 \%)$. The proportion of patients with $H A Q \leq 0.5$ among patients in remission

Table 1. Remission rates (\%) and association with $\mathrm{HAQ} \leq 0.5$

\begin{tabular}{|c|c|c|c|c|c|}
\hline \multirow{2}{*}{\multicolumn{2}{|c|}{ Remission definition }} & \multirow{2}{*}{$\begin{array}{c}\text { Remission } \\
\text { rate }\end{array}$} & \multicolumn{2}{|c|}{ HAQ $\leq 0.5(\%)$} & \multirow{2}{*}{$\begin{array}{c}\text { Adjusted OR } \\
\text { (95\%Cl) for } \\
\text { HAQ } 0.5 \text { (GEE) }\end{array}$} \\
\hline & & & $\begin{array}{l}\text { Among patients } \\
\text { in remission }\end{array}$ & $\begin{array}{l}\text { Among patients } \\
\text { in non-remission }\end{array}$ & \\
\hline \multicolumn{2}{|c|}{ ACR-EULAR boolean } & 4.5 & 87.0 & 34.1 & $2.6(2.3-2.9)$ \\
\hline \multicolumn{2}{|c|}{ CDAI $\leq 2.8$} & 13.4 & 78.5 & 27.4 & $3.2(2.9-3.5)$ \\
\hline \multicolumn{2}{|l|}{ SDAI $\leq 3.3$} & 17.1 & 78.1 & 25.7 & $3.4(3.0-3.7)$ \\
\hline \multirow[t]{2}{*}{ DAS-CRP $<1.6$} & $4 \mathrm{v}$ & 38.6 & 59.1 & 19.3 & $3.2(2.9-3.5)$ \\
\hline & $3 \mathrm{v}$ & 39.1 & 56.4 & 20.7 & $2.8(2.6-3.0)$ \\
\hline \multirow[t]{2}{*}{ DAS-ESR $<1.6$} & $4 \mathrm{v}$ & 31.7 & 63.2 & 22.6 & $3.0(2.7-3.2)$ \\
\hline & $3 \mathrm{v}$ & 30.4 & 60.4 & 24.3 & $2.6(2.4-2.8)$ \\
\hline \multirow[t]{2}{*}{ DAS28-CRP $<2.6$} & $4 \mathrm{v}$ & 34.8 & 62.8 & 20.2 & $3.3(3.0-3.6)$ \\
\hline & $3 v$ & 37.5 & 57.7 & 21.3 & $2.8(2.6-3.0)$ \\
\hline \multirow[t]{2}{*}{ DAS28-ESR $<2.6$} & $4 \mathrm{v}$ & 25.2 & 68.1 & 26.5 & $2.8(2.6-3.1)$ \\
\hline & $3 v$ & 24.4 & 62.5 & 28.7 & $2.3(2.2-2.5)$ \\
\hline \multirow[t]{2}{*}{ DAS28-CRP $\leq 1.9^{*}$} & $4 \mathrm{v}$ & 20.0 & 72.8 & 26.1 & $2.9(2.7-3.2)$ \\
\hline & $3 v$ & 21.7 & 64.5 & 27.4 & $2.3(2.2-2.5)$ \\
\hline \multirow[t]{2}{*}{ DAS28-ESR $\leq 22^{*}$} & $4 \mathrm{~V}$ & 18.4 & 71.3 & 29.9 & $2.6(2.4-2.8)$ \\
\hline & $3 v$ & 17.3 & 64.4 & 31.8 & $2.1(1.9-2.2)$ \\
\hline
\end{tabular}


was higher for the most stringent definitions. However, this also meant that, for the most stringent criteria, many patients in non-remission had $\mathrm{HAQ} \leq 0.5$. The strongest degree of association between remission and $\mathrm{HAQ} \leq 0.5$ was observed for the SDAI. However, only minor differences were noted between definitions (table 1). Sensitivity analyses yield similar results (not shown).

Conclusions: The various remission definitions confirmed their validity in terms of physical function in a large international clinical practice setting. However, many patients in non-remission will still have good functional status and being in clinical remission does not equate to having $H A Q \leq 0.5$. A multidimensional approach should be taken to help patients achieve this functional goal. Achievement of remission according to any of the indices is more important than the use of a specific index.

Disclosure of Interest: None declared

DOI: 10.1136/annrheumdis-2017-eular.3929

\section{FRI0127 OUTCOMES OF DISEASE ACTIVITY IN A 5-YEAR LARGE COHORT OF RHEUMATOID ARTHRITIS PATIENTS TREATED UNDER TREAT TO TARGET RECOMMENDATIONS AND A MULTIDISCIPLINARY CARE MODEL - A REAL-LIFE EXPERIENCE}

P. Santos-Moreno ${ }^{1}$, D. Gomez ${ }^{1}$, E. Castillo ${ }^{1}$, R. Giraldo ${ }^{1}$, G. Ballesteros ${ }^{1}$, L. Villarreal ${ }^{2}$, J. Bello $^{3}$, D. Buitrago-Garcia ${ }^{3} .{ }^{1}$ Rheumatology; ${ }^{2}$ Psychology and processes; ${ }^{3}$ Epidemiology, Biomab, Center for Rheumatoid Arthritis, Bogota, Bogota, Colombia

Background: Treat to Target (T2T) strategy becomes from the need to develop therapeutic targets and tools to achieve defined outcomes in rheumatoid arthritis (RA), this strategy has become recognized as a standard of good practice embodying the principle that rapid attainment of remission, or low disease activity, can halt joint damage and maintain good quality of life.

Objectives: The aim of this study was to describe global change in Disease Activity Score 28 (DAS28) using T2T strategy for a 60 month period in a large cohort of patients from a Colombian specialized in RA center.

Methods: A descriptive cohort study was conducted. Medical records of patients from specialized in RA center were reviewed; those patients were followed-up under T2T standards and a multidisciplinary approach. Each patient had a minimum of 6 follow-up visits. Clinical follow-up was designed by the authors according to DAS28 as follows: every $3-5$ weeks (DAS28 >5.1), every 7-9 weeks (DAS28 $\geq 3.1$ and $\leq 5.1$ ), and every $11-13$ weeks (DAS28 $<3.1$ ). Tender joint count (TJC), swollen joint count (SJC) and DAS28 were measured on each visit. Therapy had to be adjusted with DAS28 $>3.2$ unless patient's conditions don't permit it; we considered this follow-up type as implementation of a T2T strategy in patients with RA. We divided patients in four groups: remission (REM), low disease activity (LDA), moderate disease activity (MDA) and severe disease activity (SDA) patients and the aim of the study was to look at what percentage of patients who were in moderate or severe disease activity reached a low disease activity or remission. Descriptive epidemiology was done, percentages and averages were calculated; the median of each variable was analyzed using t-Student assuming normality for DAS28 distribution and the level activity disease was analyzed using Pearson's statistics.

Results: 3618 patients meet the inclusion criteria. $72 \%$ were receiving conventional DMARDs therapy and $28 \%$ were receiving biological therapy. $83 \%$ were woman and $17 \%$ were men. Mean age was 61 years \pm 11 . Mean DAS28 at beginning was $3.3 \pm 1.3$ and at the end of five year period was $2.8 \pm 0.7$. The difference of medians for DAS28 at begging and at the end showed improvement with statistical significance $(p<0.00)$. It was found a global increase in the percentage of patients in remission and LDA and decrease in moderate and severe disease activity groups (from $31 \%$ to $19 \%$ and from $12 \%$ to $2 \%$ respectively) with statistical significance.

\begin{tabular}{|l|r|r|r|r|}
\hline ACTIMTYLEVEL & \multicolumn{1}{|l|}{ TME 0 n(\%) } & $\begin{array}{l}2011-2012 \\
n(\%)\end{array}$ & $2013-2014(\%)$ & $2015-2016(\%)$ \\
\hline REM & $1512(42)$ & $1548(43)$ & $1751(48)$ & $1826(50)$ \\
\hline LDA & $536(15)$ & $955(26)$ & $969(27)$ & $1033(29)$ \\
\hline MDA & $1128(31)$ & $875(24)$ & $809(22)$ & $694(19)$ \\
\hline SDA & $442(12)$ & $240(7)$ & $89(2)$ & $65(2)$ \\
\hline
\end{tabular}

Conclusions: This study show evidence of an improvement in DAS28 and level of disease activity in a cohort of RA patients from a specialized center in Colombia treated under recommendations of T2T strategy; it was found a global increase in the percentage of patients in remission (REM) and decrease in moderate and severe disease activity groups. This revision shows the importance of T2T follow-up and a multidisciplinary treatment for the management or RA

Disclosure of Interest: None declared

DOI: 10.1136/annrheumdis-2017-eular.5589

\section{FRI0128 PRISM - PICTORIAL REPRESENTATION OF ILLNESS AND SELF MEASURE: THE USE OF A SIMPLE NON-VERBAL TOOL AS A PATIENT-CENTRED OUTCOME MEASURE IN EARLY RHEUMATOID ARTHRITIS COHORTS}

P.C. Taylor ${ }^{1}$, R. Alten ${ }^{2}$, B. Haraoui ${ }^{3}$, B. Amess ${ }^{1}$, J. Macdonald ${ }^{1}$, M. Truchon ${ }^{4}$, C. Pohl ${ }^{2}$, C. Swales ${ }^{1}$, Y. Kaneko ${ }^{5}$, T. Sensky ${ }^{6}$. ${ }^{1}$ Nuffield Department of
Orthopaedics, Rheumatology and Musculoskeletal Sciences, University of Oxford, Oxford, United Kingdom; ${ }^{2}$ Schlosspark-Klinik Charité, University Medicine Berlin, Berlin, Germany; ${ }^{3}$ Université de Montréal, Montreal; ${ }^{4}$ l'institut de Rhumatologie de Montréal, Montréal, Canada; ${ }^{5}$ Department of Internal Medicine, Keio University School of Medicine, Tokyo, Japan; ${ }^{6}$ Centre for Mental Health, Imperial College London, London, United Kingdom

Background: Treatment recommendations in early RA advocate a treat to target approach with the ideal goal of remission. But not all patients attain this goal. There is a need for outcome measures that are meaningful to patients and inform management of which alleviation of suffering is a key aim. PRISM ${ }^{1}$ is a novel, validated, brief method of measuring suffering consistent with Cassell's seminal conceptualisation ${ }^{2}$.

Objectives: To understand the relationships between a patient's perception of the totality of the impact of RA and commonly used clinical assessments of disease activity, depression and illness intrusiveness.

Methods: Basic sociodemographic and clinical data were collected from 182 RA patients from 3 international centres, assigned to one of four cohorts (two early RA and two established RA), at baseline, weeks 12 and 24. The two early RA cohorts (diagnosis $<2 \mathrm{yr}$ ) comprised Group 1 on stable treatment $(n=37)$ and Group 2 requiring csDMARD adjustment $(n=34)$. Using the IPRISM App on a tablet, all patients were asked to complete the basic PRISM task to measure self-illness separation (SIS). The smaller the SIS, the greater the person's perceived suffering. In the PRISM+ task, patients were asked to identify two valued aspects of their life at the moment $(X$ and $Y$ ) which bring pleasure, satisfaction, a sense of achievement, or a sense of purpose. The iPRISM App automatically records the distance between the centres of each of these disks and the Self disk to measure patients' perceptions of the intrusiveness of their illness on two personally valued aspects of their lives.

For both groups, direction of change in SIS and the PRISM+ measures were compared with direction of change in disease activity measures and patient global disease activity (ptGbl), assessed at wks 12 and 24, using the sign test.

Results: PRISM was easy to use and most patients understood the simple instructions. Of 182 patients at baseline, SIS showed significant correlations with ptGbl $\left(r_{s}=-0.48, p<0.0001\right)$, pain VAS $\left(r_{s}=-0.45, p<0.0001\right)$, PHQ9 $\left(r_{s}=-0.45\right.$, $p<0.0001)$ and illness intrusiveness scale $\left(r_{s}=-0.51, p<0.0001\right)$. Suffering was inversely correlated with the perceived controllability of the symptoms of RA; for Group 1, $r_{s}=0.41, p<0.0001$, for Group 2, $r_{s}=0.32, p<0.0001$.

In Group 2, SIS and DAS28-ESR showed small trends to improvement by wk 12 (DAS28-ESR $\Delta=-0.11, \mathrm{p}=0.557$; SIS $\Delta=1.7, \mathrm{p}=0.296$ ) with significant improvement by wk 24 (DAS28-ESR $\Delta=-0.82, p=0.002$; SIS $\Delta=3.85, p=0.029$ ). However, there was no significant improvement in the intrusiveness of the illness on the valued aspects of life over this time period (Actual $X, \Delta=-0.25, p=0.557$; Actual $\mathrm{Y}, \Delta=1.89, \mathrm{p}=0.169$ ).

Conclusions: PRISM is a novel PRO that quantifies factors salient to each individual with respect to the impact of RA and its treatment while allowing for incorporation of a wide range of such influences. It may have utility as an adjunct to disease activity measures in setting agreed personalised therapeutic targets.

References:

[1] T Sensky \& S Buchi. PLoS ONE 11(5):e0156284, 2016.

[2] EJ Cassell. NEJM 306:639-645,1982.

Acknowledgements: This work was financially supported by UCB in the context of an Investigator Initiated Study.

Disclosure of Interest: P. Taylor Grant/research support from: Celgene, Galapagos, GlaxoSmithKline, UCB, and Janssen, Consultant for: AbbVie, Bristol Myers Squibb, Eli Lilly and Company, GlaxoSmithKline, Merck, Pfizer, UCB, Biogen, Sandoz and Janssen, R. Alten: None declared, B. Haraoui: None declared, B. Amess: None declared, J. Macdonald: None declared, M. Truchon: None declared, C. Pohl: None declared, C. Swales: None declared, Y. Kaneko Grant/research support from: Eisai, AbbVie, Daiichisankyo, Speakers bureau: Astellas Pharma, Chugai Pharmaceutical Co, Ltd., Bristol-Myers K.K., Eisai Co., Ltd., Kissei Co., Ltd., Janssen Pharmaceutical K.K., Mitsubishi Tanabe Pharma Co., Pfizer Japan Inc., Santen Pharmaceutical Co., Taisho Toyama Pharma Co., and UCB, T. Sensky: None declared

DOI: 10.1136/annrheumdis-2017-eular.4450

\section{FRIDAY, 16 JUNE 2017}

Rheumatoid arthritis - comorbidity and clinical aspects

\section{FRI0129 COMPARATIVE SAFETY OF BIOLOGIC DMARD INITIATION IN RA: A POPULATION-BASED OBSERVATIONAL STUDY OF MALIGNANCY RISK}

S. Suissa ${ }^{1}$, S. Dell'Aniello ${ }^{1}$, T. Simon ${ }^{2}{ }^{1}{ }^{1}$ McGill University, Montreal, Canada; ${ }^{2}$ Bristol-Myers Squibb, Princeton, United States

Background: Patients (pts) with RA are at increased risk for some malignancies and the use of biologic (b)DMARDs has been reported to further increase this risk. ${ }^{1}$ Abatacept (ABA), the first selective T-cell co-stimulation modulator for RA treatment, is now often prescribed as a first-line bDMARD, but long-term effects are unknown. 